\title{
Menometrorrhagia Due to Sertraline Treatment A Case Report
}

\author{
Sertralin Kullanımına Bağlı Menometroraji: Olgu Sunumu
}

\begin{abstract}
$\mid$
(D) Sevda Bağ

ABSTRACT

Selective serotonin reuptake inhibitors are antidepressant drugs commonly used in psychiatric diseases. The most common side effects of sertraline are diarrhea, constipation, sexual side effects, fatigue, dizziness, nausea, but sertralinerelated bleeding disorder is a less common side effect. In our case, we aimed to present a case where we started sertraline, as a result of the diagnosis of depression and it seems abnormal bleeding other than menstrual time after the drug dose was increased called as menometrorrhagia and after the cessation of sertraline bleeding is ended.
\end{abstract}

University of Health Sciences Turkey, İstanbul Training and Research Hospital, Clinic of Psychiatry, İstanbul, Turkey
Keywords: Menometrorrhagia, depression, sertraline

\section{ÖZ}

Seçici serotonin geri alım inhibitörleri psikiyatrik hastalıklarda yaygın olarak kullanılan antidepresan ilaçlardır. Sertralinin en sık görülen yan etkileri ishal, kabızlık, cinsel yan etkiler, yorgunluk, baș dönmesi, mide bulantısıdır ancak sertralin ile ilișkili kanama bozukluğu daha az görülen bir yan etkidir. Biz olgumuzda depresyon tanısı koyarak sertalin bașladığımız, ilaç dozunun yükseltilmesi sonrasında adet zamanı dışında anormal kanama olarak tanımlanan menometroraji görülmesi ve sertralinin kesilmesi sonrası kanamanın gerilemesi sonucu sertraline bağlı olduğunu düșündüğümüz bir olgu sunmayı amaçladık.

Anahtar Kelimeler: Menometroraj, depresyon, sertralin

\section{Introduction}

Selective serotonin reuptake inhibitors (SSRI) are antidepressant drugs commonly used in psychiatric diseases (1). Sertraline is an SSRI molecule and is used in various psychiatric tables, primarily depression, due to its low side effects. The most common side effects of sertraline are diarrhea, constipation, sexual side effects, fatigue, dizziness, nausea, but bleeding disorder associated with sertraline is a less common side effect (2). Ecchymosis due to sertalin use was included in the cases (3). Here, we present a case with menometrorrhagia defined as abnormal bleeding after raising the drug dose from $50 \mathrm{mg} /$ day to $100 \mathrm{mg} /$ day, and whose bleeding regressed after discontinuation of sertraline, and we think that bleeding is due to sertraline.

\section{Case Report}

A 32-year-old housewife with two married children applied to our psychiatry outpatient clinic with complaints such as reluctance, loss of appetite, lack of enthusiasm, restlessness, and not enjoying life for the last 3 months. A psychiatric examination showed that her temperament was depressed and that she did not have a psychotic feature in her thought content. She didn't have a history of mental or physical illness, allergies, drug use on her resume. There was no history of mental illness in her family history. The Hamilton Depression scale applied to the patient resulted in 27 points. As a result, a diagnosis of major depression was made and sertraline $50 \mathrm{mg}$ /day was started. The dose of sertraline was increased to $100 \mathrm{mg} /$ day due to partial regression in her depressive complaints at the control three weeks later. When the history of the patient, who applied to our outpatient clinic again with the complaint of intense menstrual bleeding 3 weeks later, was questioned, it was learned that she presented to the obstetric and gynaecology clinic due to the excessive amount of bleeding that started ten days after her last menstruation, and no physical cause was found as a result of the examination and laboratory examinations. She was redirected to our outpatient clinic because it was thought to be due to sertraline use only. Blood tests were found within normal limits. In the laboratory examination; white blood cell: 5,750 cells $/ \mathrm{mm}^{3}$ (normal), red blood cell: 4,200,000 cells $/ \mathrm{mm}^{3}$ (normal), platelets: 220,000 cells $/ \mathrm{mm}^{3}$ (normal), prothrombin time: 11 seconds (normal), activated partial thromboplastin time: 29 seconds (normal), bleeding time: 4 minutes (normal), clotting time: 4 minutes (normal). There was no history of hematological disease in the patient's medical history and family history. It was recommended to discontinue sertraline due to the lack of features in blood tests 
suggestive of hematological disease and its onset after drug use. The patient's menstrual bleeding stopped three days later. It was learned that he had normal menstrual bleeding one month later. However, as the patient's depressive complaints increased, bupropion $150 \mathrm{mg} /$ day was started. During her follow-up, her depressive complaints regressed. off-cycle menstrual bleeding was not observed. Written consent was obtained from the patient.

\section{Discussion}

Excessive amount of menstrual bleeding before menstrual period in approximately the $3^{\text {rd }}$ week of the use of sertalin without any other hematological reason, the patient's not using any other medication other than the certalin and the complaints after drug withdrawal disappear and since it was confirmed by the obstetrician, this was thought to be a side effect of drug use.

Although hematological side effects related to SSRI are quite rare, case reports are available in the literature on this subject. Hematological side effects associated with SSRI use are most commonly found in Australian drug side effect reports when examining the literature (4).

The most common hematological side effects are petechiae, purpura, ecchymosis and epistaxis. In addition to superficial bleeding, gastrointestinal bleeding and intracranial bleeding are also seen (5). In a case presented by Evans et al. (6) (1991), it was suggested that the impairment in platelet functions and prolonged bleeding time of a patient who used fluoxetine and died after a subdural hematoma may be related to fluoxetine use. Many hypotheses have been put forward and many studies have been made to explain the mechanism by which SSRIs cause bleeding disorders. Platelets contain a transporter similar to the serotonin reuptake transporter found in presynaptic nerve endings. Similar to their effect on presynaptic nerve endings, SSRI's inhibit serotonin reuptake transporter in platelets, reducing or depleting the serotonin reserves of platelets. Since the presence of serotonin is necessary for platelet clustering and hemostasis function, the activity of platelet aggregation and hemostasis is also reduced as a result of decreased or depletion of the amount of serotonin (7). In our case, there were no signs of ecchymosis or superficial bleeding.

When the literature is reviewed, it is seen that there is abnormal vaginal bleeding due to antidepressants in a small number of cases (8). There is no case in the literature about the effect of using sertalin to cause heavy bleeding, except when it increases the amount of menstrual bleeding. However, in one study, it was found that the increase in serotonin activity in the central nervous system after SSRI treatment increased prolactin level by stimulation of dopamine inhibition and prolactin releasing factors; and it has been reported that the probable cause of heavy breakthrough bleeding may be that it increases the levels of luteinizing hormone, prolactin, estradiol, progesterone and inhibits gonadal steroid metabolism (9). In our case, data could not be obtained because these hormone levels could not be looked at.

In our case, as a result of menometroragia that develops due to the use of sertraline, serotonin was discontinued and replaced by bupropion.
Bupropion was recommended as SSRI without bleeding side effects when examining the literature (10) but in a meta-analysis, 3,981 studies were examined and no significant difference was found between SSRIs in terms of bleeding risk (11). However, in our case, vaginal bleeding did not recur with bupropion.

As a result, SSRI and sertraline increase the risk of bleeding. Sertraline and other SSRIs inhibit serotonin reuptake into platelets, affecting normal platelet clustering, which can result in bleeding, purpura, petechiae, ecchymosis. It is believed that this effect depends on the dose of the drug (12). Therefore, in cases where high doses are required, possible hematological side effects should be considered. We recommend that it be used more carefully in the selection of antidepressants in patients with low platelet count and/or suspected platelet dysfunction.

\section{Ethics}

Informed Consent: Written consent was obtained from the patient.

Peer-review: Externally peer-reviewed.

Financial Disclosure: The author declared that this study received no financial support.

\section{References}

1. Bottlender R, Dobmeier P, Möller HJ. The effect of selective serotonin reuptake inhibitors in blood coagulation. Fortschr Neurol Psychiatr 1998; 66: 32-5.

2. Andrade C, Sharma E. Serotonin reuptake inhibitors and risk of abnormal bleeding. Psychiatr Clin North Am 2016; 39: 413-26.

3. Cinar O, Cevik E, Kilic E, Kesim ME, Ak M. Ecchymosis due to sertraline use: a case report. Klinik Psikofarmakol Bülteni 2010; 20: 321-3.

4. Mathew T, Desmond P, Isaacs D. Bruising and bleeding with SSRI. Aust Adv Drug React Bull 1998; 17: 10-2.

5. Ay R. Ecchymosis associated with the use of paroxetine: a case report. J Clin Psy 2017; 20: 243-6.

6. Evans TG, Buys SS, Rodgers GM. Acquired abnormalities of platelet function (letter). N Engl J Med 1991; 324: 1671.

7. Hallbäck I, Hägg S, Eriksson AC, Whiss PA. Invitro effects of serotonin and noradrenaline reuptake inhibitors on human platelet adhesion and coagulation. Pharmacol Rep 2012; 64: 979-83.

8. Linnebur SA, Saseen JJ, Pace WD. Venlafaxine-associated vaginal bleeding Pharmacotherapy J Hum Pharmacol Drug Ther 2002; 22: 652-5.

9. De Abajo FJ. Effects of selective serotonin reuptake inhibitors on platelet function: mechanisms, clinical outcomes and implications for use in elderly patients. Drugs Aging 2011; 28: 345-67.

10. Na KS, Jung HY, Cho SJ, Cho SE. Can we recommend mirtazapine and bupropion for patients at risk for bleeding?: A systematic review and metaanalysis. J Affect Disord 2018; 225: 221-6.

11. Kharofa J, Sekar P, Haverbusch M, Moomaw C, Flaherty M, Kissela B, et al. Selective serotonin reuptake inhibitors and risk of hemorrhagic stroke. Stroke 2007; 38: 3049-51.

12. Shahrbabki ME, Shahrbabaki AE. Sertraline-related bleeding tendency: could it be dose-dependent? Iran J Psychiatry Behav Sci 2014; 8: 81-3. 